\title{
Methodological Approach to Determining the Strategy Efficiencyof the Economic Mechanism Development for Innovation Implementation at Engineering Enterprises
}

\author{
Alla Cherep* \\ Dean of the Faculty of Economics \\ Zaporizhzhia National University \\ Zaporizhzhia, Ukraine \\ cherep.av.znu@gmail.com
}

\author{
Alexey Hostryk \\ Department of Cybernetics and \\ Information Technologies \\ Odessa National Economic University \\ Odessa, Ukraine \\ alexeyGostrik@gmail.com
}

\author{
Olexandr Cherep \\ Department of Personnel Management \\ and Marketing \\ Zaporizhzhia National University \\ Zaporizhzhia, Ukraine \\ http://orcid.org/0000-0002-3098-0105
}

Hanna Moskaliuk

Department of Accounting and Audit

Odessa National Economic University

Odessa, Ukraine

moskaliukann@gmail.com

\author{
Iryna Mendela \\ Departament of Hoter-Rastaurant and \\ Resort Business \\ Vasyl Stefanyk Precarpathian National \\ University \\ Ivano-Frankivsk, Ukraine \\ mendela_i@ukr.net
}

\begin{abstract}
The expediency of innovation activization stimulation at industrial enterprises for the purpose of ensuring their competitiveness was proved. The methodological approach to determining the strategy efficiency of the innovation economic mechanism development (IEMD), which is based on the analysis of the main components and cover all the aspects of an enterprise's innovation development, was suggested. The approach involves comparison of the effects with the standard minimum, maximum value of the required indices, the ratio of the innovation activity integrated indices according to the established limits, which allows comparing the value of the required index and will ensure the expected effect, intensification of all activity lines and definition of the innovation main directions. In the course of the study, the limit values of fluctuations in the enterprise's innovation indices, innovation efficiency, availability of innovations at the enterprise and rate of their use were established. Accordingly, the degree of their development was found and the most optimum development strategy was selected.
\end{abstract}

Keywords - strategy, limits of fluctuations, indices, efficiency, innovation activity, intensity, development.

\section{Problem Statement}

Modern market environment is characterized by aggravation of the competition level and causes industrial enterprises to lose the niches and market segments conquered. It is the crisis conditions of development that stimulate industrial enterprises to search for alternative options for enhancing their development. This situation concerns the activities of engineering enterprises, which, on the one hand, are under impact of environmental factors and, on the other hand, have a positive effect on the socioeconomic state both of the region and state as a whole. The activities of engineering enterprises are of particular importance due to the fact that they provide goods manufactured not only for the population needs but also for functioning of many other enterprises. Under these conditions, introduction of innovations is of significance for the country's economy development and improvement of engineering enterprises' functioning. It is attraction of innovations and improvement of innovations that constitute the main way to establish enterprises' activities, increase their competitiveness level, implement development strategies and fully meet the needs of participants of this process. However, the process of enterprises' innovation development is insufficient due to a low level of innovation activity (IA), slow adaptation to variability of environmental factors, unavailability of an effective economic mechanism for innovation activity, unsystematic management decisionmaking, absence of measures for innovation implementation and introduction of innovation products.

\section{ANALYSIS OF RECENT RESEARCH AND PUBLICATIONS}

Currently, it is strategies of innovation development or innovation strategies that constitute a premise for economic growth both of industrial enterprises and the state as a whole. They contribute to increasing living standards, improving welfare, technical development, national security, gaining advantages over competitors.

That is the reason for many scholars to research the issues of formation of the innovation development strategy or innovation strategy of enterprises' activities economic growth, namely: Adamenko M. V. [15], Hrynov A. V. [1; 2], Hruba H. I. [3], Hrudzevych Y. A. [4], Homeniuk M. O. [9,], Davidov M. B. [5], Datsii O. I. [6], Dashkovska I. B. [7], Yefremov O. S. [8], Zhavoronkova H. V. [9], Zhmudenko V. O. [9], Zarichna O. I. [10], Zakharkin O. O. [11], Zakharchenko V. I. [12], Zbarzhevetska L. D. [13], Zborovska, O. M. [14], Usyk M. K. [14], Ishchenko Yu. D. [15], Kabanov A. I. [16], Kazachkov I. O. [17], Korsikova N. M. [12], Maistrenko N. V. [18], Merkulov M. M. [12], Monich O. V. [20], Nehriienko O. S. [19], Nekrasova L. A. [20], Ponomarenko L. A. [21], 
Palamarchuk V. A. [21], Ryabovolyk T. F. [13], Serdiuk B. M. [18], Stupak I. O. [7].

However, the issues of determining the strategyefficiency of the innovation economic mechanism development(IEMD) at engineering enterprises still remain unresolved.

\section{THE AIM OF THE ARTICLE}

The aim of the article is to work out a methodological approach to determining the strategy efficiency of the economic mechanism development for innovation implementation at engineering enterprises.

\section{RESUlTS}

Based on the stated above, we developed a methodological approach to determining the strategy efficiency of IEMD. We made this approach as the second component of the scientific and methodological approach to shaping the strategy of IEMD at industrial enterprises. It should be noted that the developed methodological approach to determining the strategy efficiency of IEMD is based on the analysis of the main components that cover all aspects of innovation development of the enterprise, i.e. assessment of innovation activity, level of innovation activity efficiency, availability of innovations to the enterprise and the rate of their use. The approach is implemented based on comparison of the effects with the standard minimum, maximum values of the required indices, ratio of the IA integrated indices, determination of the general level of innovation development according to the established limits, which allows selecting a more effective strategy out of the number of the existing strategy types, provided that the values of the required index are compared, which will ensure the expected effect, increase in all activities, determination of the IA main directions.

The suggested methodological approach is based on the analysis of the main components of the enterprise's innovation activity by calculating the characteristic indices for each component, further comparing the results, finding the integrated index and comparing it with the established limits, which provides for finding the required index, determining its maximum and minimum values and selecting a strategy of IEMD [22]. The advantage of this approach is selection of the most efficient strategy of IEMD, which corresponds to the established opportunities for industrial enterprises' development, possibility to improve the efficiency of the strategy development in the future, consideration of other enterprises' experiences in shaping the strategy. At the same time, the introduction of the methodological approach at engineering enterprises provides, based on the formation of strategy of IEMD, further introduction of the economic mechanism, establishment of the process of IA activation, increase in the level of innovation development, determination of innovation orientation of all activity areas [23].

The suggested methodological approach to determining the strategy efficiency of IEMD was built by implementing a complex sequence of stages. Among the main stages of this approach development there are the following: collection, analysis, processing of information on the level of innovation development of all activity areas of the enterprise; analysis of the results of financial and economic activity; determination of the analysis components; selection of coefficients for each component of the analysis which will determine the integrated index; calculation of the integrated index; establishment of limits for the calculated integrated indices and determination of their optimum level; testing of the obtained results at mechanical engineering enterprises; determination of the maximum values of the required indices and strategy selection of IEMD. Let us analyse the process of methodological approach development at each stage in detail.

At the first stage, collection, analysis and processing of information on the level of innovation development of all activity areas of the enterprise is arranged. That is, the data is collected on the level of innovation activity, innovation efficiency, availability of investment resources and an economic mechanism for IA development, interest of the company's management in improving the performance, smooth flow of innovation in production, marketing and other areas. According to the results of the collected data, the analysis is conducted and indices characterizing the level of innovation development are calculated, then the conclusion is made. At the second stage, a detailed analysis of the results of financial and economic activity is carried out, that is, financial stability, business activity, solvency, profitability of the enterprise and its ability to develop IA in the future are assessed.

At the third stage, based on the results of a comprehensive analysis of the enterprise, the components of the analysis are determined in order to make an overall assessment of the innovation development of all activity aspects. Among the main components of the analysis, the following ones were determined: level of innovation activity; innovation efficiency; availability of innovations to the enterprise and rate of their use. These components are used to compare the results and determine the level of innovation at the enterprise in general. At the fourth stage, the coefficients for calculation of each component of the analysis are selected, which allows conducting a more accurate analysis of the selected components. In addition, the value of the required integrated index depends on the availability of information, correctness of the calculation of the suggested group of indices.

The level of innovation activity is the main indicator that characterizes the enterprise's investment environment, degree of availability of investment resources to the enterprise and efficiency of their use, sufficiency of financial resources, sources of resources, effectiveness of information support, share of investment resources directed to IA development, feasibility of investment in the enterprise. It should be noted that the calculation of the level of innovation activity is carried out in accordance with the suggested group of indices (Figure 1). According to the calculation results of the given group of indices the integrated index of the level of the enterprise's innovation activity within the research period specified is determined.

The efficiency of innovation activity provides for determination of the enterprise's ability to produce innovation products and is characterized by the analysis of the rate of innovation products manufacturing, determination of the product manufacture feasibility, need to 
direct funds to innovation development, effectiveness of marketing for sale of a certain product type, size of profits from IA results and receipts from sales of innovation products, amount of expenses on IA. It is possible to assess the level of state support for innovation activities of enterprises in the given group, the main indices being presented in Figure 1.

\begin{tabular}{|} 
Innovation activity \\
level \\
Self-financing ratio \\
Information exchange \\
level in IA \\
Index of information \\
availabilityand \\
scientific information \\
dissemination \\
Index of the information \\
availability \\
level in the company \\
Efficiency of the \\
company's capital \\
investment \\
in innovation \\
Rate of investment in \\
innovation \\
Return on investment in \\
the enterprise
\end{tabular}

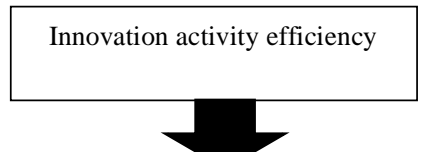

Volume of innovation products manufactured

Labour productivity of personnel involved in ID

Increment in labour productivity Profitability of operations Profitability of innovation products Profitability of innovation activity Share of profits from innovation Product innovation ratio Cost savings from introduction of modern technology

Ratio of highly qualified and skilled

workers involved in scientific work

Index of Marketing Department performance efficiency

\begin{tabular}{|c|}
\hline $\begin{array}{c}\text { Innovations availability level and rate } \\
\text { of their use at the enterprise }\end{array}$ \\
Coefficient of technology progressiveness \\
Coefficient of knowledge intensity of production \\
Capacity utilization factor in IA \\
Availability of computing technology \\
for innovation development \\
Technology innovation index \\
The ratio of own and attracted innovation technologies \\
Index of equipment availability \\
Investment rate in the production process \\
Indicator of innovation in marketing \\
Smooth production flow
\end{tabular}

Fig. 1. Calculation of innovation activity indices at the industrial enterprise

Note: developed by the authors

Availability of innovations and rate of their use is an important criterion of the enterprise's innovation development since it allows assessing availability of advanced equipment, level of updating of the deteriorated equipment, efficiency of innovation equipment operation, degree of production structure modernization, expediency of conducting R\&D, developing and introducing technologies. The analysis of the component indices contributes to determination of the enterprise's technological development level (Figure 1).

We believe that calculation of the above given indices for each component allows us to more accurately analyse the level of innovation development, reveal problem areas in the enterprise's activities, assess the degree of achievement of the general development strategy.
At the fifth stage, the calculation of the integrated index for each component is made, according to formulas 1-3:

$$
\left.I^{\text {leia }}=\sqrt[m]{\sum_{i=1}^{n} K_{1}+K_{2}}+\ldots+K_{i}\right) / n
$$

where $\mathrm{I}^{\text {leia }}-$ level of enterprise's innovation activity;

$\mathrm{K}_{\mathrm{i}}$ - value of the $\mathrm{i}$-index for the selected calculation period;

$\mathrm{m}$ - selected period of indices calculation (year);

$\mathrm{n}$ - number of indices under analysis;

$$
\left.I^{\text {leie }}=\sqrt[m]{\sum_{i=1}^{n} R_{1}+R_{2}}+\ldots+R_{i}\right) / n
$$

where $\mathrm{I}^{\text {leie }}$ - level of enterprise's innovation efficiency;

$R_{i}$ - value of the $\mathrm{i}$-index for the selected calculation period;

$$
\begin{aligned}
& \mathrm{m} \text { - selected period of indices calculation (year); } \\
& \mathrm{n} \text { - number of indices under analysis; }
\end{aligned}
$$

$$
\left.I^{\text {liaru }}=\sqrt[m]{\sum_{i=1}^{n} T_{1}+T_{2}}+\ldots+T_{i}\right) / n
$$

where $\mathrm{I}^{\text {liaru }}-$ level of innovations availability and rate of their use;

$T_{i}$ - value of the $\mathrm{i}$-index for the selected calculation period;

$$
\begin{aligned}
& \mathrm{m} \text { - selected period of indices calculation (year); } \\
& \mathrm{n} \text { - number of indices under analysis; }
\end{aligned}
$$

When calculating the integrated index, the average value of the calculated indices for each group of components is taken into account, which also allows considering the degree of effect of each index on the required value.

Based on the calculated value of the integrated index, the limits are set for each of them and their optimum level is found. The limits for integrated indices will have the form of formulas 4-6:

$$
\begin{gathered}
0,1 \neq I^{\text {leia }}>0 \\
-0,1 \neq I^{\text {leie }}>0 \\
-0,1 \neq I^{\text {liaru }}>0
\end{gathered}
$$

The value of the integrated index within «0.9-1" is optimum for the enterprise, which indicates a high level of innovation development of each component under analysis and shows that the enterprise has a high level of innovation capacity.

At the seventh stage, the results are tested at engineering enterprises, that is, the selected indices are calculated, the values of integrated indices are determined and their compliance with the specified limits is established. According to the results of this stage, it is expedient to compare the level of efficiency of each analysis component, to find out the level of the given enterprise's development.

At the eighth stage, according to the results of the analysis, the maximum values of the required indices are 
determined and limits for optimum values of each component are established in order to select a strategy of IEMD (Table 1).

TABLE I. SETTING THE LIMITS FOR FLUCTUATIONS IN INNOVATIVE DEVELOPMENT INDICES AND SELECTION OF A STRATEGY OF IEMD

\begin{tabular}{|l|c|l|}
\hline $\begin{array}{c}\text { Level of general } \\
\text { innovation } \\
\text { development }\end{array}$ & $\begin{array}{c}\text { Limits of } \\
\text { indices } \\
\text { fluctuations }\end{array}$ & \multicolumn{1}{|c|}{ Strategy type } \\
\hline Crisis & $(-1)-(-0,1)$ & - \\
\hline Pre-crisis & $(0-0,1)$ & $\begin{array}{l}\text { Active production, } \\
\text { technological, marketing, } \\
\text { innovation, investment }\end{array}$ \\
\hline Low & $(0,2-0,3)$ & $\begin{array}{l}\text { Active technological, marketing, } \\
\text { innovation, investment }\end{array}$ \\
\hline Average & $(0,4-0,5)$ & $\begin{array}{l}\text { Active marketing, innovative, } \\
\text { investment }\end{array}$ \\
\hline Above average & $(0,6)$ & Active technological, investment \\
\hline Moderate & $(0,7-0,8)$ & Active innovation, investment \\
\hline Sustained & $(0,9-1)$ & Active innovation \\
\hline $\begin{array}{l}\text { Absolutely } \\
\text { sustained }\end{array}$ & $(1,1-2)$ & Passive innovative \\
\hline
\end{tabular}

Note: made by the author

\section{CONClusions}

We established that a high level (absolutely sustained) of the enterprise's general innovation development is characterized by innovation capacity, speed of development, security of operations and profitability of activities. Based on it, it is possible to define a lack of the need for implementation of an active strategy of IEMD, which indicates feasibility of a passive strategy use, as the innovation effect increases. The condition for obtaining the general pre-crisis level of innovation development is evidence of the fact that the enterprise's problems, slowdown in innovation, deterioration of financial and economic activity and requires selection of all types of IEMD strategy to improve the performance results. In turn, a low level (crisis level) of a business entity's innovation development indicates its inability to finance activities, unprofitability of functioning, bankruptcy, which means a lack of prospects for activity renewal and non-feasibility of using the strategies useless in crises overcoming.

The suggested methodological approach to determining the strategy efficiency of IEMD was tested at engineering enterprises of Zaporizhzhia region.

\section{REFERENCES}

[1] A. V. Hrynov, Innovative development of industrial enterprises concept, methodology, strategic management. Kharkiv, Ukraine: INZHEK, 2003. [in Ukrainian].

[2] A. V. Hrynov, «Strategy of innovative development of the enterprise», Abstract D.Sc. dissertation, Donetsk National University, Donetsk, Ukraine, 2004. [in Ukrainian].

[3] H. I. Hruba, «Implementation of innovation management strategy», Economy and the state, no. 11, pp. 79-81, 2008. [Online]. Available: http://www.economy.in.ua/?n=11\&y=2008. Accessed on: July 17 , 2017. [in Ukrainian].

[4] Yu. Hrudzevych, «Characteristics of the current state of innovation development at machine-building enterprises of Ukraine», Economic Journal of Lesya Ukrainka Eastern European National University, no. 1(5), pp. 45-52, 2016. [Online]. Available: https://echasold.eenu.edu.ua/articles/kharakterystyka-suchasnohostanu-rozvytku-innovatsiinoi-diialnos. Accessed on: May 5, 2017. [in Ukrainian]
[5] M. B. Davidov, «Ways of organizational and financial support for the innovation process at enterprises of Ukraine», Actual problems of the economy, no. 4 (82), pp. 130-134, 2008. [in Ukrainian]

[6] O. I. Datsii, «Directions of improvement of innovation management mechanisms in Ukraine», Scientific Practices of the Petro Mohyla Black Sea State University, Kyiv-Mohyla Academy Complex, Series: Public Administration, vol. 147, no. 135, pp. 72-76, 2010. [Online]. Available: http://nbuv.gov.ua/UJRN/Npchdu_2010_147_135_15. Accessed on: July 17, 2017. [in Ukrainian].

[7] I. B. Dashkovska, I. O. Stupak, «Formation of the enterprise's innovation strategy on the basis of innovation potential», Business Inform, no. 11, pp. 86-88, 2011. [Online]. Available: http://www.business-inform.net/main/. Accessed on: July 18, 2017. [in Ukrainian].

[8] O. S. Yefremov, «The interconnection of main elements of the strategy of innovation development of an enterprise», Marketing and menedzhment innovations, no. 1, pp. 228-233, 2012. [Online]. Available: http://mmi.fem.sumdu.edu.ua/journals/2012/1/228-233. Accessed on: September 25, 2017. [in Ukrainian].

[9] H. V. Zhavoronkova, M. O. Gomeniuk, V. O. Zhmudenko, «Enhancement of the role of public regulation in financing of innovative activity of the region», Marketing and menedzhment innovations, no. 3, pp. 130-144, 2016. [Online]. Available: http://mmi.fem.sumdu.edu.ua/journals/2016/3/130-144. Accessed on: August 11, 2017. [in Ukrainian]

[10] O. Zarichna, «Strategy and planning innovation activity in tourism», Galician Economic Bulletin, vol. 46, no. 3, pp. 68-76,2014. [in Ukrainian].

[11] O. O. Zakharkin, «Innovation activity of an enterprise: theoretical aspect», The Problems of Economy, no. 4, pp. 274-280, 2013. [Online]. Available: http://www.problecon.com/annotatedcatalogue/?year $=2013$ \&abstract $=2013 \_04 \_0$. Accessed on: July 20, 2017. [in Ukrainian].

[12] V. I. Zakharchenko, N. M. Korsikova, M. M. Merkulov, Innovation management: theory and practice in conditions of economy transformation, Kyiv, Ukraine: Center for Educational Literature, 2012. [in Ukrainian].

[13] L. D. Zbarzhevetska, T. F. Ryabovolyk, «Influence of innovative activity of enterprises on the employment of population and economic development», Scientific Journal of Kherson State University. Series Economic Sciences, vol. 21, no. 1, pp. 28-32, 2016. [Online]. Available: http://www.ej.kherson.ua/journal/economic_21/1/8.pdf. Accessed on: August 7, 2017. [in Ukrainian].

[14] O. M. Zborovska, M. K. Usyk, «Formation of the innovation management mechanism of machine-building enterprises», Investments: practice and experience, no. 23, pp. 18-20, 2012. [Online]. $\quad$ Available: http://www.investplan.com.ua/?op=1\&z=2391\&i=4. Accessed on: July 11, 2017. [in Ukrainian].

[15] Yu. D. Ishchenko, «Territorial organization of innovative activity: theoretical methodological and practical research aspects», Ukrainian Geographic Magazine, no. 2, pp. 32-39, 2014. [Online]. Available: http://ukrgeojournal.org.ua/uk/node/444. Accessed on: August 11, 2017. [in Ukrainian].

[16] A. I. Kabanov, M. V. Adamenko, «The principles and functions of enterprise personnel innovative potential management», Agro-world, no. $5, \quad$ pp. $15-20,2017 . \quad$ [Online]. Available: http://www.agrosvit.info/?n=5\&y=2017. Accessed on: July 28, 2017. [in Ukrainian].

[17] I. O. Kazachkov, O. V. Stiempen, «Ways to support an innovative development of industrial enterprise», Economic Bulletin of Zaporizhzhya state engineering Academy: Sciences. journal, no. 5, pp. 2013. $90-97, \quad$ [Online]. Available: http://www.zgia.zp.ua/index.php?page=1292\&lang=ua. Accessed on: July 25, 2017. [in Ukrainian].

[18] N. V. Maistrenko, B. M. Serdiuk, Basis of the evaluation of efficiency innovation in enterprises, Actual problems of economics and management, no. 9, 2015. [Online]. Available: http://ape.fmm.kpi.ua/article/view/41560/43196. Accessed on: August 25, 2017. [in Ukrainian].

[19] O. S. Nehriienko, «Factors of innovation as a basis for formation of business processes at transport enterprises», Problems of improving the efficiency of infrastructure, no. 36, 2013. [Online]. Available: 
http://ecobio.nau.edu.ua/index.php/PPEI/article/view/6724. Accessed on: July 25, 2017. [in Ukrainian].

[20] L. A. Nekrasova, O. V. Monich, «Mechanism of strategy development of innovative investment companies», Ukraine's Development Strategy. Economics, sociology, law, no. 1, pp. 159163, 2014. [Online]. Available: http://jrnl.nau.edu.ua/index.php/SR/article/view/7145. Accessed on: July 21, 2017. [in Ukrainian].

[21] L. A. Ponomarenko, V. A. Palamarchuk, Innovation management, Kyiv, Ukraine: Publishing House of National Aviation University "NAU-Print", 2009. [in Ukrainian].
[22] O. H. Cherep, «Economic efficiency of the enterprise's innovation project implementation», in IX International Scientific and practical Conference. Challenges and prospects for the development of the new economy at the global, state and regional levels, Zaporihzhia, 2014.

[23] O. H. Cherep, «Problems of strategy development of the economic mechanism formation of machine-building enterprises», in Proceedings of the International Scientific and Practical conference. Problems and perspectives in European education development, Prague, 2015. 